\title{
EFFECT OF NITROGEN AND POTASSIUM FERTILIZATION ON YIELD AND FRUIT QUALITY OF MANGO KEITT CV. TREES GROWN UNDER OPEN FIELD AND SHADING CONDITIONS
}

\author{
Ola Abdel Satar ${ }^{1}$; H. El-Wakeel ${ }^{2}$; A. Abd El-Hamid ${ }^{2}$ and A. Esmail ${ }^{1}$ \\ 1- Central Laboratory for Agricultural Climate (CLAC), Agric., Research Center (ARC), Giza, \\ Egypt \\ 2- Hort. Dept. Fac. of Agric. Ain Shams Univ., Cairo, Egypt
}

[36]

Keywords: Fertilization, Mango cv. Keitt, Nitrogen, Potassium, Shading, Yield

\section{ABSTRACT}

This study was carried out during three successive seasons of 2010/2011, 2011/2012 and 2012/2013 in a private orchard at $76 \mathrm{~km}$ Cairo, Alex. Desert road to investigate the effect of nitrogen and potassium fertilization treatments and shading with white net on yield, and fruit quality of three-years-old mango (Mangifica indica L.) cv. Keitt grafted on sucary seedling rootstocks planted at $2.5 \times 2.5$ meters apart grown in sandy soil under drip irrigation system with wells water. This experiment included nine treatments of fertilization: $\mathrm{T} 1=$ $\mathrm{N} 80+\mathrm{K}_{2} \mathrm{O} 80 \mathrm{Kg} /$ Fed., $\mathrm{T} 2=\mathrm{N} 80+\mathrm{K}_{2} \mathrm{O} 100$ $\mathrm{Kg} /$ Fed., T3 $=\mathrm{N} 100+\mathrm{K}_{2} \mathrm{O} 80 \mathrm{Kg} / \mathrm{Fed}$., T4= N 100+ $\mathrm{K}_{2} \mathrm{O} 100 \mathrm{Kg} / \mathrm{Fed}$., $\mathrm{T} 5=\mathrm{N} 120+\mathrm{K}_{2} \mathrm{O} 80 \mathrm{Kg} / \mathrm{Fed}$., $\mathrm{T} 6=\mathrm{N} 120+\mathrm{K}_{2} \mathrm{O} 100 \mathrm{Kg} / \mathrm{Fed} ., \mathrm{T} 7=\mathrm{N} 150+\mathrm{K}_{2} \mathrm{O} 80$ $\mathrm{Kg} / \mathrm{Fed}$., $\mathrm{T} 8=\mathrm{N} 150+\mathrm{K}_{2} \mathrm{O} 100 \mathrm{Kg} / \mathrm{Fed}$. and control (T9) $=\mathrm{N} 133+\mathrm{K}_{2} \mathrm{O} 90 \mathrm{Kg} / \mathrm{Fed}$.. The results cleared that mango Keitt $\mathrm{cv}$. trees grown under white net shading condition significantly increased yield (kg)/ tree, number of fruit set/ panicle, fruit weight, TSS and ascorbic acid content. Trees supplied with 150 $\mathrm{Kg} /$ Fed. nitrogen $+100 \mathrm{Kg} /$ Fed. potassium exhibited the highest yield $(\mathrm{kg}) /$ tree, number of fruit set/panicle and fruit weight under shade. Moreover, the best fruit peel color was achieved with trees received $100 \mathrm{~kg} / \mathrm{feddan}$ of nitrogen +100 $\mathrm{kg} / \mathrm{feddan}$ of potassium and grown under screenhouse conditions during the three studied seasons. The higher significant value of acidity and TSS were recorded in trees supplied by 120 units of nitrogen +100 units of potassium during first and third season. Whereas, the control treatment attained a maximum ascorbic acid content.

\section{INTRODUCTION}

Mango (Mangifera indica L.) is one of the popular and economically important tropical fruit throughout the world and is praised due to its delicious taste, unique and attractive flavor with high nutritive value. Mango trees planted under Egyptian condition total produced about 927352 tons from a total area of 265350 fed with an average yield of 4.40 tons per fed (Bulletin of the agricultural statistics 2014).

Keitt is a late maturing cultivar and its harvest season is from September to October. The average weight of Keitt fruit is $900 \mathrm{~g}$ and the skin colour is a pale green.

Nutrient management is deem one of the important components of mango production technology. Application of balanced amount of nutrients at right growth stage by proper method could return in improved quality and yield of mango because imbalanced fertilization is considered to be one of the major contributing factors for the low productivity.

Nitrogen plays a most important role in various physiological processes. It imparts dark-green color in plants, promotes leaves, stem and other vegetative part's growth and development. Moreover, it also stimulates root growth. Nitrogen produce rapid early growth, improve fruit quality, enhances the growth of leafy vegetables, increases protein content of fodder crops; It encourages the uptake and utilization of other nutrients including potassium, phosphorous and controls overall growth of plant (Bloom, 2015). 
Reddy et al (2000) designated that $\mathrm{N}$ application significantly influenced the fruit yield of young Totapuri cv. mango trees while $\mathrm{P}$ and $\mathrm{K}$ application did not. Average fruit size and total soluble solids of pulp were significantly influenced by $\mathrm{N}$ nutrition during the tenth year but other fruit quality attributes were unaffected. $\mathrm{N}$ at $50 \mathrm{~g} /$ tree/year of age resulted in the best canopy development while $\mathrm{N}$ at $100 \mathrm{~g} /$ tree/year of age gave maximum fruit yield. The yield was very poor when $\mathrm{N}$ was not applied and with very high $\mathrm{N}$ rates also.

Potassium is one of the major nutrient that need to be provided in relatively large quantities to fruit crop plants. It is the most abundant cation in the cytoplasm and it makes a major contribution to the osmotic potential of cells. There is a evident relationship between potassium accumulation in the plant tissues, including fruits, and their carbohydrate content (Marschner, 1995).

Singh et al (2009) studied the effect of NPK levels on twenty four years old mango cv. Langar trees. On the basis of cumulative yield (2003-09) maximum yield of $52.67 \mathrm{~kg} /$ tree was recorded in the treatment N2P1K1 (200N:50P:100K g/plant per year) which was significantly superior to other treatments. This is followed by the treatment N2P2K1 (200N:100P:100K g/plant per year) which gave yield of $51.01 \mathrm{~kg} / \mathrm{plant}$ which was at par with N2P1K1 (100N:50P:100K g/plant per year). Minimum yield $(17.02 \mathrm{~kg} /$ treatments) was noted in control (NOPOKO). El-Wakeel (2005) indicated that urea at 500 or $1000 \mathrm{~g} \mathrm{~N}$ per tree and potassium sulfate at $400 \mathrm{~g} \mathrm{~K} 2 \mathrm{O}$ per tree, registered the greatest fruit weight, length, width and thickness in mango (cv. Amrapali) at Dibba Al-Fujira, United Arab Emirates. The optimum temperature for growing mangoes is 24.0 to $27.0^{\circ} \mathrm{C}$.

Temperatures below $18.0^{\circ} \mathrm{C}$ reduce the growing rate, while temperatures over $37.0^{\circ} \mathrm{C}$ cause high temperature injury to the mango (Yasutomi et al 1994). Fruit growth and maturation, dependent on physiological, biochemical and even physical processes, are influenced by prevailing temperatures during the developmental period. Particularly, after flower bud formation has occurred, it is essential to use a screen net to maintain a temperature, promotes fruit set, and reduces the incidence of anthracnose and effect of weather conditions during flowering, fruit set and fruiting. Shading improved the appearance of fruits through the reduction of split pit, sunburn and wind damage.

Wind and excess solar radiation are some of the factors severely influencing the growth, yield and quality of mango in the hot climate. Excessive light, however, can negatively affect appearance of the fruits. Mango growers have been using spraying white protective wetable powders such as "Kaolin" or aerothene caps for sun protection (Fivaz and Lonsdale, 2001) (Jutamanee and Onnom, 2016). In this concern, Medany et al (2009) evaluated the effects of white net on the growth and production of mango cv. Keitt trees from the interception of light, temperature, humidity and plant growth. The use of white net resulted in a significant increase of plant height and stem diameter per plant compared to open field orchard. The net was superior for plant growth, flowering and yield. Data revealed that microclimate under the white net make proper microclimate for tropical fruits under Egyptian conditions. Pavel et al (2000) investigated effect of shading up on incidences of bacterial black spot and sunburn, flowering, yield and fruit quality in mango cv. 'Kent' and 'Heidi'. Results showed that shade led to increased fruit yield and the number of fruits per tree increased by 284 and $1410 \%$ in Kent and Heidi, respectively.

This study aimed was to investigate the effect of nitrogen and potassium fertilization levels on vegetative growth some chemical traits of fruits and yield of mango Keitt cv. grown under open field and shading conditions.

\section{MATERIALS AND METHODS}

The experiment was carried out during the three successive seasons of 2010/2011, 2011/2012 and 2012/2013, at a private orchard located at Cairo-Alexandria desert road $(\mathrm{km} .76$ Cairo - Alex) to study the response of Keitt mango trees to different nitrogen and potassium fertilization levels under shading and open field conditions. Total of 90 trees mango Mangifera indica $\mathrm{L}$. cv. Keitt three-years-old grafted on Sucary seedling rootstock and planted at $2.5 \times 2.5$ meters apart, grown in sandy soil (Tables 1 and 2) under drip irrigation system were used in the experiment.

The Nitrogen and potassium fertilization was applied to mango trees as ammonium nitrate (33\% $\mathrm{N})$ and potassium sulphate $\left(50 \% \mathrm{~K}_{2} \mathrm{O}\right)$ respectively. These treatments were applied under shading and open field conditions. Shading condition is represented by screenhouse which covered with white screen net ( $40 \%$ shading). All trees under investigation were selected to be uniform in vigor as far as possible and subjected to the same agricultural practices.

The factorial experiment was laid out in split block design with five replications and one tree for each replicate. The data were recorded as follow: 
Keitt cv. Trees grown under Open field and shading conditions

Table 1. Physical and chemical properties of the experiment soil.

\begin{tabular}{|c|c|c|c|c|c|c|c|c|}
\hline & \multicolumn{8}{|c|}{ Physical properties } \\
\hline & $\begin{array}{c}\text { Sand } \\
\%\end{array}$ & $\begin{array}{c}\text { Clay } \\
\%\end{array}$ & $\begin{array}{c}\text { Silt } \\
\%\end{array}$ & \multicolumn{5}{|c|}{ Texture } \\
\hline & 95.31 & 4.30 & 0.36 & \multicolumn{5}{|l|}{ Sandy } \\
\hline & \multicolumn{8}{|c|}{ Chemical properties } \\
\hline & $\begin{array}{c}E C \\
d S / m\end{array}$ & $\mathrm{PH}$ & $\begin{array}{l}\mathrm{Ca}^{++} \\
\mathrm{meq} / \mathrm{I}\end{array}$ & $\begin{array}{c}\mathrm{Mg}^{++} \\
\mathrm{meq} / \mathrm{I}\end{array}$ & $\begin{array}{c}\mathrm{Na}^{+} \\
\mathrm{meq} / \mathrm{I}\end{array}$ & $\begin{array}{c}\mathrm{K}^{+} \\
\mathrm{meq} / \mathrm{I}\end{array}$ & $\begin{array}{l}\mathrm{HCO}^{-} \\
\mathrm{meq} / \mathrm{I}\end{array}$ & $\begin{array}{c}\mathrm{Cl}^{-} \\
\mathrm{meq} / \mathrm{I}\end{array}$ \\
\hline $0-30$ & 2.8 & 7.4 & 6.0 & 3.0 & 20.1 & 1.2 & 2.6 & 13.0 \\
\hline $30-60$ & 3.00 & 7.8 & 6.5 & 3.6 & 22.1 & 1.9 & 3.1 & 15.2 \\
\hline & \multicolumn{8}{|c|}{ Macro - nutrients available $(\mathrm{mg} / \mathrm{l})$} \\
\hline & $\mathrm{N}$ & $\mathrm{P}$ & $\mathrm{K}$ & & & & & \\
\hline $0-30$ & 32 & 6 & 56 & & & & & \\
\hline $30-60$ & 35 & 8 & 58 & & & & & \\
\hline
\end{tabular}

The experiment included 9 fertilization treatments as follows:

\begin{tabular}{|c|l|}
\hline No. & Treatment \\
\hline N1K1 & $80 \mathrm{~kg} \mathrm{~N}+80 \mathrm{~kg} \mathrm{~K}{ }_{2} \mathrm{O} /$ feddan/year \\
N1K2 & $80 \mathrm{~kg} \mathrm{~N}+100 \mathrm{~kg} \mathrm{~K} \mathrm{~K}_{2} \mathrm{O} /$ feddan /year \\
$\mathrm{N} 2 \mathrm{~K} 1$ & $100 \mathrm{~kg} \mathrm{~N}+80 \mathrm{~kg} \mathrm{~K}{ }_{2} \mathrm{O} /$ feddan /year \\
$\mathrm{N} 2 \mathrm{~K} 2$ & $100 \mathrm{~kg} \mathrm{~N}+100 \mathrm{~kg} \mathrm{~K} \mathrm{O}_{2} \mathrm{O}$ feddan /year \\
$\mathrm{N} 3 \mathrm{~K} 1$ & $120 \mathrm{~kg} \mathrm{~N}+80 \mathrm{~kg} \mathrm{~K} \mathrm{O} /$ feddan /year \\
$\mathrm{N} 3 \mathrm{~K} 2$ & $120 \mathrm{~kg} \mathrm{~N}+100 \mathrm{~kg} \mathrm{~K} \mathrm{O} /$ feddan /year \\
$\mathrm{N} 4 \mathrm{~K} 1$ & $150 \mathrm{~kg} \mathrm{~N}+80 \mathrm{~kg} \mathrm{~K} \mathrm{O} /$ feddan /year \\
$\mathrm{N} 4 \mathrm{~K} 2$ & $150 \mathrm{~kg} \mathrm{~N}+100 \mathrm{~kg} \mathrm{~K} \mathrm{~K}_{2} \mathrm{O} /$ feddan /year \\
Control & $130 \mathrm{~kg} \mathrm{~N}+90 \mathrm{~kg} \mathrm{~K} \mathrm{O}_{2} \mathrm{O}$ feddan /year \\
\hline
\end{tabular}

\section{a) Yield and fruit quality}

\section{The yield $(\mathbf{k g}) /$ tree}

At harvest time (maturity stage on 23,29 and 25 September during the three seasons, respectively), yield / tree was determined as number and average weight of fruits $(\mathrm{g})$. The estimated yield $\mathrm{kg} / \mathrm{tree}$ was recorded.

- Number of fruit set/ panicle

\section{Fruit physical characteristics}

Three mango fruits of each tree at maturity stage on 23, 29 and 25 September during the three seasons, respectively were used to carry out the following measurements:

- Fruit weight $(\mathrm{g})$

- Peel color (hue angle)
- Peel color was estimated by using a Minolta colorimeter type (CR-400/410) for the estimation of $a, b$ and hue angle $\left(h^{\circ}\right)$.

- Hue angle $\left(\mathrm{h}^{\circ}=\operatorname{arc} \tan -1 \mathrm{~b}^{*} / \mathrm{a}^{*}\right)$ determines the red, yellow, green, blue, purple, or intermediate colors between adjacent pairs of these basic colors.

Hue angle $\left(0^{\circ}=\right.$ red-purple, $90^{\circ}=$ yellow, $180^{\circ}=$ bluish-green, $270^{\circ}=$ blue $),=270^{\circ}$, as described by McGuire (1992) Fig. (1)

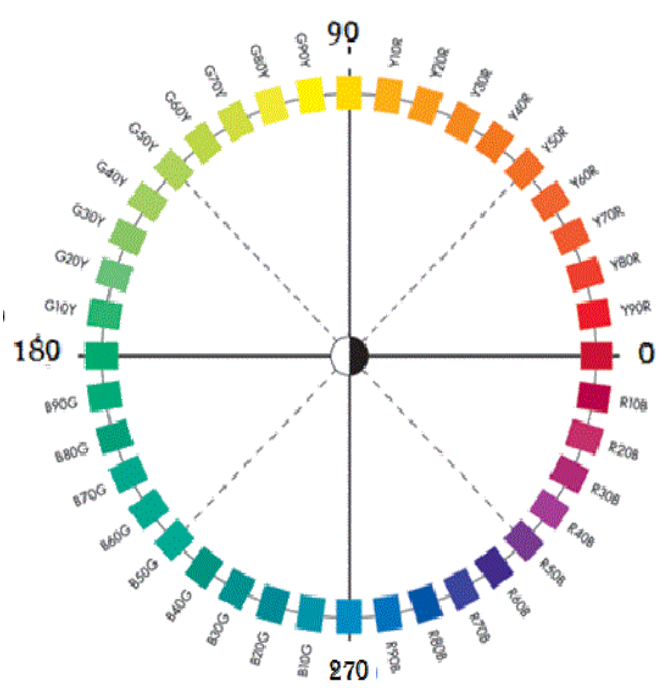

Fig. 1. Hue angle diagram anglediagram 


\section{Fruit chemical characteristics}

- Total soluble solid (TSS) of fruits for replicate of each treatment were determined in fruit juice by a hand refractometer.

- Total acidity percentage was determined in fruit juice according to (A.O.A.C., 1995)

- Ascorbic acid content was determined in fruit juice according to (methods of vitamin Assay ,1966).

\section{Statistical analysis}

The obtained data were subjected to analysis of variance (ANOVA) according to Snedecor and Cochran (1980) using MSTAT program. Duncan's multiple range tests at $5 \%$ level was used for means comparing Duncan (1955).

\section{RESULTS AND DISCUSSION}

\section{Yield kg/tree}

The impacts of nitrogen and potassium fertilization treatments on mango yield recorded significant effect as shown in (Table 2). There was an increasing trend of yield with the increasing rate of fertilizers. The highest yield $(15.69,16.33$ and $16.85 \mathrm{~kg} /$ tree) was found in the treatment 150 $\mathrm{kg} / \mathrm{feddan}$ of nitrogen $+100 \mathrm{~kg} / \mathrm{feddan}$ of potassium compared to the lowest yield $(2.25,3.49$ and $2.42 \mathrm{~kg} / \mathrm{tree}$ ) by $80 \mathrm{~kg} / \mathrm{feddan}$ of nitrogen +80 $\mathrm{kg} / \mathrm{feddan}$ of potassium during all studied seasons respectively.

Touching to screenhouse impact, trees under shading conditions had significantly higher yield than to those under open field conditions during the three seasons of study.

The interaction between the two studied factors cleared that the treatment $150 \mathrm{~kg} /$ feddan of nitrogen $+100 \mathrm{~kg} /$ feddan of potassium under shading condition had the highest significant yield in all studied seasons. Whereas, the lowest yield was obtained from the treatment combination of 80 $\mathrm{kg} / \mathrm{feddan}$ of nitrogen $+80 \mathrm{~kg} / \mathrm{feddan}$ of potassium under open field conditions in the 1st and the 3rd seasons but under screenhouse condition in the second season.

\section{Number of fruit set/ panicale}

The results in Table (3) indicated significant effect of nitrogen and potassium fertilization on mango cv. Kiett trees. The highest initial fruit setting was recorded in the treatment $150 \mathrm{~kg} /$ feddan of nitrogen $+100 \mathrm{~kg} / \mathrm{feddan}$ of potassium in all studied seasons. While, treatment $80 \mathrm{~kg} / \mathrm{feddan}$ of nitrogen $+80 \mathrm{~kg} / \mathrm{feddan}$ of potassium had the lowest values during all studied seasons.

Regarding to shading impact, the application of shading led to significant increase in initial fruit set during the three seasons where trees grown under screen house gained highest fruit set compared to trees grown under open field condition.

As for the interaction, $150 \mathrm{~kg} / \mathrm{feddan}$ of nitrogen+ $100 \mathrm{~kg} / \mathrm{feddan}$ of potassium under screenhouse condition recorded the highest significant value in the three growing seasons whilst, the lowest significant values were obtained from 80 $\mathrm{kg} / \mathrm{feddan}$ of nitrogen $+80 \mathrm{~kg} / \mathrm{feddan}$ of potassium under open field conditions in all three seasons.

\section{Fruit physical characteristics}

\section{Fruit weight (g)}

Data tabulated in (Table 4) recorded significant effect of nitrogen and potassium fertilization application on mango. There was an increasing trend of fruit weight with the increasing rate of fertilization, where the highest fruit weight $(1111,1080$ and $891 \mathrm{~g}$ ) was found in the treatment $150 \mathrm{~kg} / \mathrm{feddan}$ of nitrogen $+100 \mathrm{~kg} / \mathrm{feddan}$ of potassium compared to the lowest fruit weight $(710.3,575.7$ and $560.7 \mathrm{~g})$ obtained by trees fertilized with $80 \mathrm{~kg} / \mathrm{feddan}$ of nitrogen $+80 \mathrm{~kg} / \mathrm{feddan}$ of potassium during all studied seasons, respectively.

Concerning screenhouse impact, trees under shading conditions had significantly higher fruit weight than to those under open field conditions.

The interaction between the two studied factors, the treatment of nitrogen at $150 \mathrm{~kg} / \mathrm{feddan}+$ potassium at $100 \mathrm{~kg} / \mathrm{feddan}$ under shading condition had the highest significant fruit weight in all studied seasons. While, the lowest fruit weight was obtained from the treatment combination of nitrogen at $80 \mathrm{~kg} / \mathrm{feddan}+$ potassium at $80 \mathrm{~kg} / \mathrm{feddan}$ under open field conditions in all three seasons.

\section{Fruit colour}

\section{Peel color}

Results showed in Table (5) indicate the influence of nitrogen and potassium fertilization under open field and screenhouse conditions treatments on peel color of mango Cv. Keitt 
Keitt cv. Trees grown under Open field and shading conditions 
Keitt cv. Trees grown under Open field and shading conditions 
Keitt cv. Trees grown under Open field and shading conditions

The highest peel color was noticed with treatment having nitrogen at $100 \mathrm{~kg} / \mathrm{feddan}+$ potassium at $100 \mathrm{~kg} / \mathrm{feddan}$.Increasing nitrogen levels significantly reduced the peel color of mango cv. Keitt fruits whereas lower values of peel color were produced with applying nitrogen at $150 \mathrm{~kg} /$ feddan and potassium at $80 \mathrm{~kg} / \mathrm{feddan}, 150 \mathrm{~kg} / \mathrm{feddan}$ of nitrogen $+100 \mathrm{~kg} / \mathrm{feddan}$ of potassium, $120 \mathrm{~kg} /$ feddan of nitrogen $+80 \mathrm{~kg} / \mathrm{feddan}$ of potassium and control treatments in the first, second and third seasons, respectively, than those of other treatments.

As for shading condition, the greatest value of peel color was found with shading treatment compared with open field treatment.

Concerning the effect of interaction between fertilization treatments with nitrogen and potassium and open field or screenhouse conditions the results showed that the highest fruit peel color was achieved with trees received $100 \mathrm{~kg} / \mathrm{feddan}$ of $\mathrm{ni}-$ trogen $+100 \mathrm{~kg} /$ feddan of potassium and grown under screen house conditions during the three studied seasons.

\section{Fruit chemical characteristics}

\section{Total Soluble Solids (TSS)}

Data regarding T.S.S are shown (Table 6). Results proved that TSS was affected significantly by fertilization treatments The highest values were recorded by $120 \mathrm{~kg} /$ feddan of nitrogen +100 $\mathrm{kg} / \mathrm{feddan}$ of potassium in the first and the third seasons but $120 \mathrm{~kg} / \mathrm{feddan}$ of nitrogen +80 $\mathrm{kg} / \mathrm{feddan}$ of potassium in the second season. Whereas, the lowest significant value was obtained by $80 \mathrm{~kg} / \mathrm{feddan}$ of nitrogen $+80 \mathrm{~kg} / \mathrm{feddan}$ of potassium in the first and the third seasons meanwhile, $80 \mathrm{~kg} / \mathrm{feddan}$ of nitrogen $+100 \mathrm{~kg} / \mathrm{feddan}$ of potassium in the second season.

Concerning screenhouse impact, trees under shading conditions significantly recorded higher TSS value than to those on open field conditions except for second season.

With respect to interaction between fertilization treatments and screenhouse conditions, 120 $\mathrm{kg} / \mathrm{feddan}$ of nitrogen $+100 \mathrm{~kg} / \mathrm{feddan}$ of potassium under shading condition achieved the highest significant value in the first and the third seasons while $120 \mathrm{~kg} / \mathrm{feddan}$ of nitrogen $+80 \mathrm{~kg} / \mathrm{feddan}$ of potassium under open field conditions in the second season. On the contrary, the lowest significant value was noticed in trees treated with 80 $\mathrm{kg} / \mathrm{feddan}$ of nitrogen $+80 \mathrm{~kg} / \mathrm{feddan}$ of potassium under open field condition in seasons of 2011and 2013.Meanwhile, $80 \mathrm{~kg} / \mathrm{feddan}$ of nitrogen +100 $\mathrm{kg} / \mathrm{feddan}$ of potassium under shading condition was the lowest significant value in the second season.

\section{Total Acidity}

Effect of nitrogen and potassium fertilization treatments on total acidity showed significant differences (Table 7). Total acidity in $80 \mathrm{~kg} /$ feddan of nitrogen $+80 \mathrm{~kg} / \mathrm{feddan}$ of potassium was found minimum during all studied seasons. Contrary, maximum acidity value was observed in 120 $\mathrm{kg} / \mathrm{feddan}$ of nitrogen $+100 \mathrm{~kg} / \mathrm{feddan}$ of potassium in the first and the third seasons however, 120 $\mathrm{kg} / \mathrm{feddan}$ of nitrogen $+80 \mathrm{~kg} / \mathrm{feddan}$ of potassium had highest significant value in the second season.

Touching screenhouse effect, shading condition demonstrated highest significant value in the first and the third season but in the second season insignificant difference could be noticed.

The result noted the significant combined effect of fertilization treatments and shading condition on total acidity. The trees fertilized with $80 \mathrm{~kg} / \mathrm{feddan}$ of nitrogen $+80 \mathrm{~kg} / \mathrm{feddan}$ of potassium in open field registered the lowest value at the first and the third season but $80 \mathrm{~kg} / \mathrm{feddan}$ of nitrogen +80 $\mathrm{kg} / \mathrm{feddan}$ of potassium under screenhouse condition at the second season. In addition, The combination of $120 \mathrm{~kg} / \mathrm{feddan}$ of nitrogen+ $100 \mathrm{~kg} / \mathrm{feddan}$ of potassium under screenhouse condition in the first and the third season while $120 \mathrm{~kg} / \mathrm{feddan}$ of nitrogen $+80 \mathrm{~kg} / \mathrm{feddan}$ of potassium under screenhouse condition in the second season showed higher significant values than some of other treatments.

\section{Ascorbic acid content}

Fertilization treatments exhibited significant differences with regard to ascorbic acid content (Table 8) among the fertilization treatments, the treatment control attained a maximum ascorbic acid content in all seasons against the minimum value in application of $80 \mathrm{~kg} / \mathrm{feddan}$ of nitrogen + $80 \mathrm{~kg} / \mathrm{feddan}$ of potassium in all studied seasons. Also, the treatment of $120 \mathrm{~kg} / \mathrm{feddan}$ of nitrogen + $100 \mathrm{~kg} / \mathrm{feddan}$ of potassium gave the same highest significant value in the third season.

Regarding the screenhouse effect, trees under shading conditions continued to record significantly higher ascorbic acid content than to those under open field condition. 
Keitt cv. Trees grown under Open field and shading conditions 
Keitt cv. Trees grown under Open field and shading conditions

The interaction between the two studied factors, the combination of control treatment $(133 \mathrm{~kg}$ $\mathrm{N}+90 \mathrm{~kg} \mathrm{~K}{ }_{2} \mathrm{O} /$ Fed. /year) under screenhouse conditions of resulted in the highest ascorbic acid content in the three growing seasons while, the lowest significant values were obtained by 80 $\mathrm{kg} / \mathrm{feddan}$ of nitrogen $+80 \mathrm{~kg} / \mathrm{feddan}$ of potassium under open field conditions in all three seasons.

\section{CONCLUSION}

Finally, the obtained results revealed that application of nitrogen at $150 \mathrm{~kg} / \mathrm{feddan}$ plus potassium at $100 \mathrm{~kg} /$ feddan significantly increased yield $\mathrm{kg} /$ tree, fruit set and number of fruit / panicle and fruit weight of mango cv. Keitt. Moreover, the best fruit peel color was achieved with trees received $100 \mathrm{~kg} / \mathrm{feddan}$ of nitrogen $+100 \mathrm{~kg} / \mathrm{feddan}$ of potassium and grown under screenhouse conditions in the three studied seasons. On the other hand, treatment of $80 \mathrm{~kg} / \mathrm{feddan}$ of nitrogen+ 80 $\mathrm{kg} / \mathrm{feddan}$ of potassium under open field gave the lowest significant values for yield/tree and fruit weight. This result are in harmony with those found Singh et al (2009) and El-Wakeel (2005) who reported that some levels of nitrogen and potassium at different rates improved yield and fruit quality of some mango cv. trees.

Results also cleared that shading mango cv. Keitt trees using white screen net found to be superior in increasing fruit production in terms of yield $\mathrm{kg} /$ tree,fruit set/ panicle, fruit number and weight and this effect may be due to improving the microclimate under shading throughout reducing air temperature, sun irradiance and increasing the relative humidity around the mango trees. This result are in harmony with those obtained by Crété et al (2001) who reported that indicating a $2-6 \%$ increase in humidity associated with the use of nets. Moreover, reported a decrease in evaporation by $11 \%$ in July associated with the use of nets and a significant reduction in wind speed, which also resulted in a decrease in skin bruising. Dutta et al (2011) and Pavel et al (2000) they noticed that yield and fruit quality of Kent and Heidi cv. improved by shading.

\section{REFERENCES}

Association of Vitamin Chemists. 1966. Methods of Vitamin Assay, Interscience publishers, $3^{\text {rd }}$ ed. New York, USA, p. 287.
A.O.A.C. 1995. Association of Official Agricultural Chemists Official Methods of Analysis, A.O.A.C. $16^{\text {th }}$ Ed. Washington, D.C., U.S.A.

Bulletin of the Agricultural Statistics. 2014. Ministry of Agriculture \& land Reclamation. Economic Affairs Sector, the $2^{\text {nd }}$ Part p. 282.

Bloom, A.J. 2015. The increasing importance of distinguishing among plant nitrogen sources. Current Opinion in Plant Biology, 25, 10-16.

Crété, X., J.L. Regnard, G. Ferre and C. Tronel (2001). Effects secondaires et conséquences sur la conduite du verger. L'arboriculture fruitière, 553, 51-55.

Duncan, D.B. 1955. Multiple range and multiple F tests. Biometrics, 11, 1-42.

Dutta, P., Ahmed, B. and Kundu, S. 2011. Effect of different sources of potassium on yield, quality, and leaf mineral content of mango in West Bengal. Better Crops - South Asia, pp16-18.

El-Wakeel, H.F. 2005. Preliminary studies on fertilization of mango trees under U.A.E. conditions: II - Response of Amrapali mango trees to nitrogen and potassium fertilization. Annals Agric. Sci., 50 (2), 563-572.

Fivaz, J. and Lonsdale J. 2001. Mango production under shade cloth. S.A. Mango Grower Assoc. newsletter. 4, 2-3.

Jutamanee, K. and Onnom S. 2016. Improving photosynthetic performance and some fruit quality traits in mango trees by shading. Photosynthetica. 54(4), 542-550.

McGuire, R.G. 1992. Reporting of Objective Color Measurements. Hort. Science, 27(12), 12541255.

Marschner H. 1995. Mineral Nutrition of Higher Plants, Academic Press, London ( $2^{\text {nd }}$ Ed.) p. 889.

Medany, M.A., Abdrabbo M.A.A., Awny A.A., Hassanien M.K. and Abou-Hadid A.F. 2009. Growth and productivity of mango grown under greenhouse conditions. Egyptian Journal of Horticulture, 36(2), 373-382.

Pavel, E.W., Oosthuizen, R.G. and Mthembu G.J. 2000. Effect of shading upon incidences of bacterial blackspot and sunburn, flowering, yield and fruit quality in mango. South African Mango Growers' Association Yearbook, 19 \& 20, 100-102.

Reddy, Y.T.N., Kurian R.M., Kohli R.R. and Gorakh Singh. 2000. Effect of nitrogen, phosphorus and potassium on growth, yield and fruit quality of 'Totapuri' mango (Mangifera indica). 
Indian Journal of Agricultural Sciences. Snedecor, G.W. and Cochran W.G. 1980. Statis70(7), 475-478

Singh T.K., Kumar A., Singh D.B. and Singh J. 2009. Effect of NPK on growth and yield of mango (Mangifera indica L.). Progressive Horticulture, 41(2), 240-243. tical Methods, $7^{\text {th }}$ ed. lowa State, Univ. Press. Ames, lowa, U.S.A. p.507.

Yasutomi T.; Toma T. and Uechi T. 1994. Official guidebook for fruit tree cultivation, Mango. Okinawa Prefectural Government, Naha, Japan, pp. 173-194. 